\title{
Influence of Altitude, Latitude and Season of Collection (Bergmann's Rule) on the Dimensions of Lutzomyia intermedia (Lutz \& Neiva, 1912) (Diptera, Psychodidae, Phlebotominae)
}

\author{
Carlos Brisola Marcondes ${ }^{+}$, Ana Leuch Lozovei*, Aloisio Falqueto**, \\ Reginaldo P Brazil $* * *$, EAB Galati****, GM Aguiar*****, NA Souza*****
}

\begin{abstract}
Departamento de Microbiologia e Parasitologia, Centro de Ciências Biológicas, Universidade Federal de Santa Catarina, Campus Trindade, 88040-900 Florianópolis, SC, Brasil *Departamento de Patologia Básica, SCB, UFPR, Curitiba, PR, Brasil **Centro Biomédico, UFES, Vitória, ES, Brasil ***Centro de Pesquisas René Rachou, Fiocruz, Belo Horizonte, MG, Brasil ****Faculdade de Saúde Pública, USP, São Paulo, SP, Brasil *****Departamento de Entomologia, Instituto Oswaldo Cruz, Rio de Janeiro, RJ, Brasil
\end{abstract}

The influence of altitude and latitude on some structure sizes of Lutzomyia intermedia was noted; several structures of insects collected in higher localities were greater, according to Bergmann's rule. This influence was more remarkable in two localities of the State of Espirito Santo, probably due to greater differences in altitude. Comparing insects from different latitudes, more differences were noted in comparisons of insects from low altitude localities than in those of material from higher altitudes. The small number of differences between insects collected in July and in December does not indicate a defined influence of season and temperature on the size of adults. The possible epidemiological implications of these variations are discussed.

Key words: altitude - latitude - Phlebotominae - Lutzomyia intermedia - Bergmann’s Rule

The relationship between size and temperature was initially observed for endothermic animals and extended to insects, constituting Bergmann's rule (James 1970, Atkinson 1994). The altitude and latitude, in which the insects develop, through the temperature, can influence their size.

Lane (1988) cited preliminary studies on the influence of temperature upon the size of Lutzomyia longipalpis (Lutz \& Neiva, 1912). This may be related to their fertility (Honek 1993) and epidemiological role (Haramis 1983, Kelly \& Edman 1992). Lu. intermedia (Lutz \& Neiva, 1912), redescribed by Marcondes (1996), has been incriminated as a vector of parasites causing cutaneous leishmaniasis (Rangel et al. 1984, Barros et al. 1985, Pereira \& Hoch 1990, Aguiar 1993). Leishmania chagasi Cunha \& Chagas, 1937 (Paraense \& Chagas, 1940) and L. braziliensis Vianna, 1911 (Rangel et al. 1992), experimentally infected insects of this species. Several measurements of in-

\footnotetext{
${ }^{+}$Corresponding author. Fax: $+55-48-331.9258$. E-mail: cbrisola@mbox1.ufsc.br

Received 8 September 1998

Accepted 10 May 1999
}

sects of this species from localities in the Brazilian states of Espírito Santo, Rio de Janeiro and São Paulo were taken. Insects collected in the winter and in the summer, in one of the localities, were also compared, to check the occurrence of seasonal variation in size (cyclomorphism). The influence of altitude, latitude and season upon the size of this species and their possible relationship to the epidemiology of cutaneous leishmaniasis was analyzed.

\section{MATERIALS AND METHODS}

The work was developed with specimens collected in the following municipalities: Venda Nova do Imigrante [Espírito Santo (ES), 20 20' 23" S $41^{\circ} 08^{\prime} 05^{\prime}$ ' W, $750 \mathrm{~m}$ above sea level], Viana (ES, $20^{\circ} 23^{\prime} 25^{\prime \prime} \mathrm{S} 40^{\circ} 29^{\prime} 46^{\prime}$ 'W, $30 \mathrm{~m}$ a. s. 1.), Cordeiro [Rio de Janeiro (RJ), $21^{\circ} 59^{\prime} 02^{\prime \prime} \mathrm{S} 42^{\circ} 15^{\prime} 10^{\prime \prime}$ W, $266 \mathrm{~m}$ a. s. 1.], Petrópolis (RJ, $22^{\circ} 15^{\prime} 14^{\prime \prime} \mathrm{S}$ $43^{\circ} 04^{\prime} 25^{\prime}$ W, $490 \mathrm{~m}$ a. s. 1.), Cachoeiras de Macacu (RJ, 22 27' 45" S 420 39' 11" W, $58 \mathrm{~m}$ a. s. 1.), Itaguaí (RJ, $22^{\circ} 51^{\prime} 08^{\prime \prime} \mathrm{S} 43^{\circ} 46^{\prime} 01^{\prime}$ ' W, 13 $\mathrm{m}$ a. s. 1.), Niterói (RJ, $22^{\circ} 53^{\prime}$ ' S $43^{\circ} 06^{\prime} 13^{\prime \prime}$ W, 5 m a. s. 1.), Parati (RJ, $23^{\circ} 13^{\prime} 04^{\prime \prime} \mathrm{S} 44^{\circ} 42^{\prime} 47^{\prime}$ " W, 5 m a. s. 1.), Rio Bonito (RJ, 22 $42^{\prime} 30^{\prime}$ ' S $42^{\circ}$ 37' 34" W, 62 m a. s. 1.), Ubatuba [São Paulo (SP), $23^{\circ} 26^{\prime} 12^{\prime \prime} \mathrm{S} 45^{\circ} 04^{\prime} 16^{\prime \prime} \mathrm{W}, 3 \mathrm{~m}$ a. s. 1.] and São

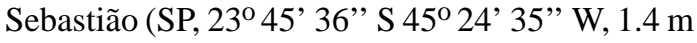
a. s. 1.). 
The samples from Venda Nova do Imigrante, Cordeiro and Petrópolis were considered as coming from high altitude and the others from low altitude. The samples from Venda Nova do Imigrante and Viana were considered as coming from lower latitude and the others from higher latitude. The comparisons related to latitude were made separately for the groups of higher and lower latitude. Samples of insects collected in June and in December 1994 in Venda Nova do Imigrante were compared.

The insects were mounted in NC medium (Nelson Cerqueira, Enecê in Portuguese) (Cerqueira 1943) or using the Berlese method. Modifications in the measurements resulting from the preparation method (Marcondes et al. 1997) were corrected before the statistical analysis was made. Thirty-nine structures and distances, listed by Marcondes (1997), as well as the various ratios between measurements, were established for insects of both sexes.
The data were analysed by ANOVA, with a Confidence Limit of $5 \%(\mathrm{P}<0,05)$ and $1 \%(\mathrm{P}<0,01)$ level, using Excel 4.0 program. The Coefficient of Variation was calculated by: C. V. $=\frac{100 . s}{m}$, where $s$ is the standard deviation and $m$ is the mean, graded from extremely good to extremely bad (Ferreira 1991).

\section{RESULTS}

Tables I and II show, respectively for females and males from the State of Espírito Santo, the results of insects from higher localities and from lower ones which differed significantly. The specimens of both sexes collected from Venda Nova do Imigrante showed several dimensions greater than those from Viana. Most differences were significant at $1 \%$, probably indicating a positive influence of altitude upon the dimensions.

Tables III and IV show the analogous results for females and males from the states of Rio de Janeiro and São Paulo. The length of Antennomere

\section{TABLE I}

Dimensions (in $\mu \mathrm{m}$ ) of females and some of their respective ratios for Lutzomyia intermedia from Venda Nova do Imigrante (750 m a. s. 1.) and Viana (30 m a. s. 1.), in the State of Espírito Santo

\begin{tabular}{|c|c|c|c|c|c|c|c|c|}
\hline \multirow[b]{2}{*}{ Sizes and ratios } & \multicolumn{4}{|c|}{ Venda Nova do Imigrante } & \multicolumn{4}{|c|}{ Viana } \\
\hline & Mean & $\mathrm{s}$ & $\mathrm{N}$ & C. V. & Mean & $\mathrm{s}$ & $\mathrm{N}$ & C. V. \\
\hline Length of head ${ }^{b}$ & 388.7 & 12.5 & 50 & 3.2 & 369.4 & 25.4 & 19 & 6.9 \\
\hline Width of head ${ }^{b}$ & 370.9 & 14 & 41 & 3.8 & 342.6 & 12.2 & 17 & 3.6 \\
\hline Length of eye ${ }^{b}$ & 221 & 13.6 & 47 & 6.2 & 200.4 & 11 & 17 & 5.5 \\
\hline Width of eye $e^{b}$ & 126.7 & 8.06 & 47 & 6.4 & 110.6 & 8.8 & 17 & 7.9 \\
\hline Length of palpomere $3^{b}$ & 178.4 & 7.6 & 46 & 4.3 & 163.5 & 6.6 & 15 & 4 \\
\hline Length of palpomere $5^{b}$ & 151.2 & 14.5 & 45 & 9.6 & 135.3 & 11.5 & 14 & 8.5 \\
\hline Total length of palpus $b$ & 601 & 25.4 & 45 & 4.2 & 552 & 21.5 & 14 & 3.9 \\
\hline Length of labrum ${ }^{b}$ & 355 & 15.9 & 52 & 4.5 & 330.7 & 10.7 & 19 & 3.2 \\
\hline Antennomere III $^{b}$ & 242.1 & 16.6 & 44 & 6.9 & 221.6 & 11.6 & 18 & 5.2 \\
\hline Length of mesonotum ${ }^{b}$ & 612.7 & 20.7 & 50 & 3.4 & 561.3 & 39.5 & 16 & 7 \\
\hline Length of wing ${ }^{b}$ & 2170 & 118 & 47 & 5.4 & 2056 & 102 & 15 & 5 \\
\hline Maximum width wing $b$ & 657 & 29.3 & 47 & 4.5 & 576 & 29.9 & 13 & 5.2 \\
\hline \multicolumn{9}{|l|}{ Length of wing/ } \\
\hline length of mesonotum ${ }^{a}$ & 3.75 & 0.194 & 13 & 5.18 & 3.60 & 0.182 & 11 & 5.08 \\
\hline$\alpha\left(\text { length of } \mathrm{R}_{2}\right)^{b}$ & 635 & 43.2 & 49 & 6.8 & 547 & 30.4 & 13 & 5.5 \\
\hline$\beta$ (length of $\left.\mathrm{R}_{2+3}\right)^{a}$ & 315.4 & 32.1 & 50 & 10.2 & 295.7 & 26.7 & 13 & 9 \\
\hline$\alpha / \beta^{b}$ & 2.04 & 0.26 & 49 & 12.6 & 1.86 & 0.19 & 13 & 10.2 \\
\hline$\delta^{b}$ & 339.6 & 38.4 & 50 & 11.3 & 278 & 34.2 & 12 & 15 \\
\hline Length of $\mathrm{R}_{3}{ }^{b}$ & 777 & 44.8 & 49 & 5.8 & 683 & 30.1 & 13 & 4.4 \\
\hline$\pi^{b}$ & 197.5 & 30.7 & 49 & 15.6 & 166.9 & 30.4 & 13 & 18.2 \\
\hline Length of $\mathrm{R}_{5}^{b}$ & 1450 & 46.6 & 50 & 3.2 & 1323 & 56.7 & 14 & 4.3 \\
\hline Length of posterior femur $b$ & 829 & 41.6 & 37 & 5 & 772 & 41.6 & 6 & 5.4 \\
\hline Length of median femur $b$ & 784 & 41.1 & 40 & 5.2 & 712 & 50.8 & 9 & 7.1 \\
\hline Length of anterior femur $b$ & 775 & 38.5 & 42 & 5 & 692 & 33.8 & 11 & 4.9 \\
\hline Total length of spermatheca $b$ & 57.37 & 6.2 & 49 & 10.9 & 51.91 & 6 & 19 & 11.6 \\
\hline Length of spermathecal head ${ }^{a}$ & 12.34 & 2.1 & 50 & 16.8 & 11.13 & 1.7 & 19 & 15.1 \\
\hline Length of spermathecal body ${ }^{a}$ & 45.06 & 6 & 49 & 13.3 & 40.94 & 5.9 & 19 & 14.3 \\
\hline Length of common duct ${ }^{a}$ & 40.85 & 8.5 & 35 & 20.8 & 34.72 & 8.8 & 14 & 25.2 \\
\hline
\end{tabular}

$\mathrm{s}$ : standard deviation; N: Number of observations; C.V. : coefficient of variation; $a$ : significant at $5 \%$; $b$ : significant at $1 \% ; \delta$ : distance between the distal extremity of $R_{1}$ and the fork of $R_{2+3} ; \pi$ : distance between the fork of $R_{4}$ and $\mathrm{R}_{2+3}$ and that of $\mathrm{M}_{1+2}$. 
III and of the genital filaments of males and the length of the wings of females were even greater in the insects from the low altitude localities. The variation of the measurements was low; the C.V. exceeded $10 \%$ only in some of them, mostly in those of female genitalia.

In comparisons of different altitudes, Tables $\mathrm{V}$ and VI show the significantly different results between localities of high altitude, for females and males, respectively. Tables VII and VIII show the similar results for low altitude localities. In the insects of either sex collected at the low altitude localities, several structure sizes were greater in those from higher latitudes, contrasting with the comparisons from the high altitude localities, in which most dimensions were greater in the insects from Venda Nova do Imigrante. Only the ratio length of wing/maximum width of wing of females was greater in insects from Viana.

Table IX shows the significantly different dimensions of female insects collected in June and in December 1994. No significant differences were noted between dimensions of males, possibly because the number of studied insects of June was small.

\section{DISCUSSION}

The number of differences between the specimens from localities of high altitudes in Rio de Janeiro and those of low altitudes in this State and in São Paulo were smaller than those observed in the comparisons of insects from the state of Espírito Santo. The contrasting result of the genital filaments, Antennomere III and length of wings (Tables III and IV) is probably related to the relatively lower altitude of the "high" localities of Rio de Janeiro, when compared to that of Venda Nova do Imigrante.

The ratio length of wing/length of mesonotum was greater in female insects of high altitude localities of the states of Espírito Santo and Rio de Janeiro than in those from lower altitudes. Com-

TABLE II

Dimensions (in $\mu \mathrm{m}$ ) of males for Lutzomyia intermedia of Venda Nova do Imigrante (750 m a. s. 1.) and Viana (30 $\mathrm{m}$ a. s. 1.), in the State of Espírito Santo

\begin{tabular}{|c|c|c|c|c|c|c|c|c|}
\hline \multirow[b]{2}{*}{ Sizes } & \multicolumn{4}{|c|}{ Venda Nova do Imigrante } & \multicolumn{4}{|c|}{ Viana } \\
\hline & Mean & $\mathrm{s}$ & $\mathrm{N}$ & C. V. & Mean & $\mathrm{s}$ & $\mathrm{N}$ & C. V. \\
\hline Interocular distance $^{a}$ & 100.3 & 5.5 & 28 & 5.5 & 95.8 & 7.6 & 15 & 7.9 \\
\hline Length of head $b$ & 342.8 & 10.5 & 31 & 3 & 318.6 & 12.1 & 17 & 3.8 \\
\hline Width of head ${ }^{b}$ & 332.2 & 10.8 & 28 & 3.3 & 315.6 & 14 & 15 & 4.4 \\
\hline Length of palpomere $3^{b}$ & 140.2 & 7.8 & 29 & 5.6 & 126.5 & 6.8 & 17 & 5.4 \\
\hline Length of palpomere $5^{b}$ & 139.4 & 9.6 & 29 & 6.9 & 124.2 & 9.3 & 14 & 7.5 \\
\hline Total length of palpus $b$ & 490 & 19.1 & 29 & 3.9 & 445.7 & 18.7 & 14 & 4.2 \\
\hline Length of labrum ${ }^{a}$ & 234.1 & 9.6 & 30 & 4.1 & 226.4 & 9.8 & 17 & 4.3 \\
\hline Length of Antennomere III ${ }^{a}$ & 250.6 & 12.7 & 15 & 5.1 & 239.1 & 14.6 & 15 & 6.1 \\
\hline Length of eye $e^{b}$ & 213.1 & 11.2 & 29 & 5.3 & 198 & 10.4 & 17 & 5.2 \\
\hline Width of eye $\mathrm{e}^{b}$ & 116.5 & 5 & 28 & 4.3 & 110.4 & 8.3 & 15 & 7.5 \\
\hline Length of mesonotum ${ }^{b}$ & 526.5 & 21.2 & 29 & 4 & 483 & 25 & 16 & 5.2 \\
\hline Length of wing $b$ & 1888 & 78.4 & 31 & 4.2 & 1783 & 111 & 15 & 6.2 \\
\hline Maximum width of wing $b$ & 547 & 28 & 31 & 5.1 & 487 & 28.9 & 14 & 5.9 \\
\hline Length of $\mathrm{R}_{2}^{b}$ & 513.4 & 33.9 & 29 & 6.6 & 448.6 & 33 & 15 & 7.4 \\
\hline Length of $\mathrm{R}_{2+3} b$ & 287.2 & 25.8 & 30 & 9 & 250.5 & 16.1 & 15 & 6.4 \\
\hline$\delta^{b}$ & 260.1 & 38.1 & 29 & 14.6 & 222.6 & 35.3 & 14 & 15.9 \\
\hline Length of $\mathbf{R}_{3}^{b}$ & 630 & 39.8 & 29 & 6.3 & 578.7 & 40.1 & 15 & 6.9 \\
\hline$\pi^{b}$ & 185.9 & 23.8 & 28 & 12.8 & 162.8 & 25.8 & 15 & 15.8 \\
\hline Length of $\mathrm{R}_{5}{ }^{b}$ & 1255 & 52.7 & 28 & 4.2 & 1130 & 45.6 & 14 & 4 \\
\hline Length of anterior femur $b$ & 707 & 26.5 & 30 & 3.7 & 653 & 75 & 13 & 11.5 \\
\hline Length of median femur $b$ & 701 & 35.1 & 26 & 5 & 624 & 44.2 & 14 & 7.1 \\
\hline Length of posterior femur $b$ & 746 & 30.2 & 28 & 4 & 678 & 38.2 & 14 & 5.6 \\
\hline Length of coxite ${ }^{b}$ & 297.7 & 13.1 & 31 & 4.4 & 287.8 & 11.2 & 16 & 3.9 \\
\hline Length of style $\mathrm{e}^{b}$ & 145 & 6.4 & 31 & 4.6 & 135 & 7.8 & 17 & 5.8 \\
\hline Length of paramere ${ }^{b}$ & 189 & 10.3 & 30 & 5.4 & 177.5 & 7.9 & 17 & 4.5 \\
\hline Length of lateral lobe $e^{b}$ & 292.6 & 10.8 & 31 & 3.7 & 271 & 9.8 & 17 & 3.6 \\
\hline Length of genital pump ${ }^{b}$ & 215.5 & 9.9 & 30 & 4.6 & 198 & 10.5 & 17 & 5.3 \\
\hline
\end{tabular}

s: standard deviation; N: Number of observations; C.V. : coefficient of variation; $a$ : significant at $5 \%$; $b$ : significant at $1 \% ; \delta$ : distance between the distal extremity of $\mathrm{R}_{1}$ and the fork of $\mathrm{R}_{2+3} ; \pi$ : distance between the fork of $\mathrm{R}_{4}$ e $\mathrm{R}_{2+3}$ and that of $\mathrm{M}_{1+2}$. 


\section{TABLE III}

Dimensions (in $\mu \mathrm{m}$ ) of females and some of their respective ratios for Lutzomyia intermedia from higher localities of the State of Rio de Janeiro (RJ) and from lower localities of the States of Rio de Janeiro and São Paulo (SP)

\begin{tabular}{|c|c|c|c|c|c|c|c|c|}
\hline \multirow[b]{2}{*}{ Sizes and ratios } & \multicolumn{4}{|c|}{ High altitude : RJ } & \multicolumn{4}{|c|}{ Low altitude: RJ/ SP } \\
\hline & Mean & s & $\mathrm{N}$ & C. V. & Mean & $\mathrm{s}$ & $\mathrm{N}$ & C. V. \\
\hline Length of head $b$ & 401.8 & 17.7 & 23 & 4.4 & 381 & 23.8 & 64 & 6.2 \\
\hline Length of eye $\mathrm{e}^{b}$ & 234 & 13 & 21 & 5.58 & 222 & 14.2 & 56 & 6.4 \\
\hline Width of eye ${ }^{b}$ & 136.8 & 7.7 & 22 & 5.62 & 126.7 & 8.3 & 55 & 6.6 \\
\hline Total length of eye ${ }^{b}$ & 634 & 35.4 & 20 & 5.59 & 580 & 29.2 & 58 & 5 \\
\hline Length of Antennomere III ${ }^{a}$ & 236.4 & 23.8 & 21 & 10.05 & 224.8 & 17.6 & 63 & 7.8 \\
\hline Length of mesonotum ${ }^{b}$ & 605 & 35.9 & 24 & 5.94 & 574 & 27.9 & 63 & 4.9 \\
\hline Length of wing $b$ & 2007 & 96.6 & 23 & 4.81 & 2080 & 112 & 62 & 5.4 \\
\hline Maximum width of wing ${ }^{a}$ & 639 & 34.6 & 24 & 5.41 & 621 & 36.4 & 64 & 5.9 \\
\hline Length/maximum width of wing $b$ & 3.14 & 0.18 & 23 & 5.78 & 3.35 & 0.22 & 61 & 6.7 \\
\hline Length of wing/length of mesonotum ${ }^{b}$ & 3.31 & 0.19 & 23 & 5.7 & 3.64 & 0.23 & 59 & 6.2 \\
\hline Length of $\mathrm{R}_{2}{ }^{a}$ & 611 & 47.2 & 24 & 7.72 & 585 & 56.8 & 65 & 9.71 \\
\hline Length of $\mathrm{R}_{3}^{2} a$ & 751 & 42.4 & 24 & 5.64 & 723 & 60.2 & 65 & 8.3 \\
\hline Maximum width of spermatheca $b$ & 17.97 & 1.19 & 17 & 6.63 & 16.8 & 1.56 & 61 & 9.34 \\
\hline
\end{tabular}

s: standard deviation; $\mathrm{N}$ : number of observations; C.V. : coefficient of variation; $a$ : significant at $5 \% ; b$ : significant at $1 \%$.

\section{TABLE IV}

Dimensions (in $\mu \mathrm{m}$ ) of males for Lutzomyia intermedia from higher localities of the State of Rio de Janeiro (RJ) and from lower localities of the States of Rio de Janeiro and São Paulo (SP)

\begin{tabular}{|c|c|c|c|c|c|c|c|c|}
\hline \multirow[b]{2}{*}{ Sizes and ratios } & \multicolumn{4}{|c|}{ High altitude: RJ } & \multicolumn{4}{|c|}{ Low altitude: RJ/ SP } \\
\hline & Mean & $\mathrm{s}$ & $\mathrm{N}$ & C.V. & Mean & $\mathrm{s}$ & $\mathrm{N}$ & C. V. \\
\hline Length of Antennomere III $^{a}$ & 220.7 & 17.9 & 33 & 8.1 & 235.1 & 20.3 & 79 & 8.6 \\
\hline Length of mesonotum ${ }^{a}$ & 511 & 23.3 & 32 & 4.6 & 494 & 22.1 & 43 & 4.5 \\
\hline Length of $\mathrm{R}_{2}^{b}$ & 492 & 54.9 & 33 & 11.2 & 461 & 37.3 & 39 & 8.1 \\
\hline Length of posterior femur ${ }^{a}$ & 705 & 27.2 & 24 & 3.9 & 688 & 27.3 & 35 & 4 \\
\hline Length of coxite ${ }^{a}$ & 291 & 10.4 & 33 & 3.6 & 283 & 18 & 46 & 6.4 \\
\hline Length of paramere ${ }^{b}$ & 207.8 & 28.6 & 30 & 13.8 & 182.6 & 14.9 & 45 & 8.2 \\
\hline Length of lateral lobe $e^{b}$ & 294 & 17.2 & 31 & 5.8 & 276 & 12.1 & 46 & 4.4 \\
\hline Length of genital pump ${ }^{b}$ & 213.2 & 8.1 & 33 & 3.8 & 206.2 & 12 & 46 & 5.8 \\
\hline Length of genital filaments ${ }^{a}$ & 280.8 & 56 & 32 & 20 & 302 & 27.6 & 46 & 9.2 \\
\hline
\end{tabular}

s: standard deviation; N: number of observations; C.V. : coefficient of variation; $a$ : significant at $5 \%$; $b$ : significant at $1 \%$.

paring the females from high and low altitude localities, this ratio was greater in females from lower latitudes. This ratio was greater in Drosophila melanogaster bred at higher temperatures, and probably influences its flight capability (David et al. 1994). The results obtained from the study of Lu. intermedia indicate a contradictory effect of altitude and of latitude on this ratio, not pointing out a definite influence of temperature for this species.

Considering that there were many significant differences in the comparisons between insects from Venda Nova do Imigrante and those from Viana (Tables I and II), the effect of altitude on structure sizes of $L u$. intermedia seems to be much greater than that of the latitude. Possibly, a com- parison between insects from localities in the Northeast of Brazil and those of Rio de Janeiro and São Paulo would reveal significantly differences.

The differences between the apparent influence of latitude on the dimensions in different altitudes (Tables VII and VIII vs. Tables V and VI) could be caused by the much higher altitude of Venda Nova do Imigrante, compared to those of the localities of Rio de Janeiro, and to the smaller differences of latitude between the localities of higher altitude.

Although the insects collected in June probably developed at lower temperatures than those collected in December, there was no tendency to greater structure sizes among the former. This could 
TABLE V

Dimensions (in $\mu \mathrm{m}$ ) of females and some of their respective ratios for Lutzomyia intermedia from high altitude localities of the States of Espírito Santo (Venda Nova do Imigrante) and of Rio de Janeiro (Cordeiro and

Petrópolis)

\begin{tabular}{|c|c|c|c|c|c|c|c|c|}
\hline \multirow[b]{2}{*}{ Sizes and ratios } & \multicolumn{4}{|c|}{ Venda Nova do Imigrante (ES) } & \multicolumn{4}{|c|}{ Cordeiro and Petrópolis (RJ) } \\
\hline & Mean & $\mathrm{s}$ & $\mathrm{N}$ & C. V. & Mean & $\mathrm{s}$ & $\mathrm{N}$ & C. V. \\
\hline Interocular distance $^{b}$ & 119.4 & 8.57 & 41 & 7.18 & 111.9 & 10.8 & 20 & 9.7 \\
\hline Length of head ${ }^{b}$ & 389 & 12.5 & 50 & 3.22 & 402 & 17.7 & 23 & 4.41 \\
\hline Width of head ${ }^{b}$ & 370 & 14 & 41 & 3.77 & 385 & 18.3 & 16 & 4.75 \\
\hline Length of eye $\mathrm{e}^{b}$ & 221 & 13.6 & 47 & 6.17 & 234 & 13.05 & 21 & 5.58 \\
\hline Width of eye $\mathrm{e}^{b}$ & 126.7 & 8.06 & 47 & 6.36 & 136.7 & 7.69 & 22 & 5.62 \\
\hline Length of palpomere $3^{a}$ & 178.5 & 7.72 & 45 & 4.32 & 173.7 & 7.86 & 20 & 4.52 \\
\hline Length of palpomere $5^{b}$ & 151.2 & 14.6 & 45 & 9.64 & 139.7 & 14.1 & 20 & 10.1 \\
\hline Total length of palpus ${ }^{b}$ & 601 & 25.4 & 45 & 4.22 & 634 & 35.4 & 20 & 5.59 \\
\hline Length of labrum $b$ & 355 & 15.9 & 52 & 4.47 & 337.8 & 21.5 & 24 & 6.36 \\
\hline Length of wing ${ }^{b}$ & 2170 & 118 & 47 & 5.44 & 2007 & 96.6 & 23 & 4.81 \\
\hline $\begin{array}{l}\text { Length of wing/ length } \\
\text { of mesonotum }\end{array}$ & 3.55 & 0.21 & 45 & 6.02 & 3.31 & 0.19 & 23 & 5.7 \\
\hline Maximum width of wing ${ }^{a}$ & 657 & 29.3 & 47 & 4.46 & 639 & 34.6 & 24 & 5.41 \\
\hline Length of $\mathrm{R}_{2}{ }^{a}$ & 635 & 43.2 & 49 & 6.8 & 611 & 47.2 & 24 & 7.72 \\
\hline Length of $\mathrm{R}_{2+3} b$ & 315 & 32.1 & 50 & 10.2 & 291 & 29.6 & 24 & 10.2 \\
\hline Length of $\mathrm{R}_{3}+\frac{3}{a}$ & 777 & 44.8 & 49 & 5.76 & 751 & 42.4 & 24 & 5.64 \\
\hline Length of $\mathbf{R}_{5} b$ & 1450 & 46.6 & 50 & 3.21 & 1389 & 58.8 & 24 & 4.23 \\
\hline Length of posterior femur ${ }^{a}$ & 829 & 41.6 & 37 & 5.02 & 800 & 43.6 & 21 & 5.44 \\
\hline Length of median femur ${ }^{b}$ & 784 & 41.1 & 40 & 5.34 & 746 & 47.2 & 19 & 6.33 \\
\hline Length of anterior femur ${ }^{b}$ & 775 & 38.5 & 42 & 4.97 & 735 & 30.8 & 23 & 4.2 \\
\hline Total length of spermatheca $b$ & 57.37 & 6.24 & 49 & 10.9 & 50.84 & 7.95 & 17 & 15.8 \\
\hline Length of head of spermatheca ${ }^{a}$ & 12.33 & 2.08 & 50 & 16.8 & 11.02 & 2.46 & 17 & 22.3 \\
\hline Maximum width of spermatheca $b$ & 15.7 & 2.05 & 50 & 13.02 & 17.97 & 1.19 & 17 & 6.63 \\
\hline Max. w. spermathecal head ${ }^{a}$ & 11.57 & 1.67 & 50 & 14.4 & 12.73 & 1.63 & 17 & 12.8 \\
\hline
\end{tabular}

s: standard deviation; $\mathrm{N}$ : number of observations; C.V.: coefficient of variation; $a$ : significant at $5 \%$; $b$ : significant at $1 \%$.

TABLE VI

Dimensions (in $\mu \mathrm{m}$ ) of males for Lutzomyia intermedia from high altitude localities of the States of Espírito Santo (Venda Nova do Imigrante) and of Rio de Janeiro (Cordeiro and Petrópolis)

\begin{tabular}{|c|c|c|c|c|c|c|c|c|}
\hline \multirow[b]{2}{*}{ Structures } & \multicolumn{4}{|c|}{ Venda Nova do Imigrante (ES) } & \multicolumn{4}{|c|}{ Cordeiro and Petrópolis (RJ) } \\
\hline & Mean & $\mathrm{s}$ & $\mathrm{N}$ & C. V. & Mean & $\mathrm{s}$ & $\mathrm{N}$ & C. V. \\
\hline Length of palpomere $3^{b}$ & 140.2 & 7.8 & 29 & 5.6 & 133 & 8 & 33 & 6 \\
\hline Total length of palpus ${ }^{b}$ & 490 & 19.1 & 29 & 3.9 & 466 & 30.2 & 33 & 6.5 \\
\hline Length of Antennomere III $^{b}$ & 250.6 & 12.7 & 23 & 5.1 & 220.7 & 17.9 & 33 & 8.1 \\
\hline Length of labrum ${ }^{a}$ & 234.1 & 9.6 & 30 & 4.1 & 225.2 & 17.9 & 30 & 7.9 \\
\hline Length of mesonotum ${ }^{b}$ & 526 & 21.2 & 29 & 4 & 510.7 & 23.3 & 32 & 4.6 \\
\hline Length of wing $b$ & 1888 & 78.4 & 31 & 4.2 & 1742 & 77.8 & 33 & 4.5 \\
\hline Maximum width of wing ${ }^{a}$ & 547.5 & 28 & 31 & 5.1 & 531 & 27 & 33 & 5.1 \\
\hline Length of $\mathrm{R}_{2+3} b$ & 287.2 & 25.8 & 30 & 9 & 264.6 & 25.2 & 33 & 9.5 \\
\hline Length of $\mathrm{R}_{3}^{2+3}$ & 630.4 & 39.8 & 29 & 6.3 & 598 & 56.1 & 33 & 9.4 \\
\hline$\pi^{a}$ & 185.9 & 23.8 & 28 & 12.8 & 168.6 & 31.3 & 33 & 18.5 \\
\hline Length of $\mathrm{R}_{5}^{b}$ & 1255 & 52.7 & 28 & 4.2 & 1166 & 56.8 & 32 & 4.9 \\
\hline Length of posterior femur $b$ & 746 & 30.2 & 28 & 4 & 704 & 27.2 & 24 & 3.8 \\
\hline Length of median femur ${ }^{b}$ & 701 & 35.1 & 26 & 5 & 662 & 28.5 & 29 & 4.3 \\
\hline Length of anterior femur ${ }^{b}$ & 707 & 26.5 & 30 & 3.7 & 666 & 31.5 & 27 & 4.7 \\
\hline Length of coxite ${ }^{a}$ & 297.7 & 13 & 31 & 4.4 & 291.3 & 10.4 & 33 & 3.6 \\
\hline Length of paramere ${ }^{b}$ & 189.1 & 10.3 & 30 & 5.4 & 207.8 & 28.6 & 30 & 13.8 \\
\hline Length of genital filaments ${ }^{a}$ & 308 & 15.5 & 30 & 5 & 280.8 & 56 & 32 & 20 \\
\hline
\end{tabular}

s: standard deviation; $\mathrm{N}$ : number of observations; C.V.: coefficient of variation; $a$ : significant at $5 \% ; b$ : significant at $1 \%$; $\pi$ : distance between fork of $\mathrm{R}_{4}$ and $\mathrm{R}_{2+3}$ and that of $\mathrm{M}_{1+2}$. 


\section{TABLE VII}

Dimensions (in $\mu \mathrm{m}$ ) of females and some of their respective ratios for Lutzomyia intermedia from Viana, a low altitude and lower latitude locality in the State of Espírito Santo (ES), and from low altitude and higher latitude localities in the states of Rio de Janeiro and São Paulo

\begin{tabular}{|c|c|c|c|c|c|c|c|c|}
\hline \multirow[b]{2}{*}{ Structures and ratios } & \multicolumn{4}{|c|}{ Viana (ES) } & \multicolumn{4}{|c|}{ Rio de Janeiro and São Paulo } \\
\hline & Mean & $\mathrm{s}$ & $\mathrm{N}$ & C. V. & Mean & $\mathrm{s}$ & $\mathrm{N}$ & C. V. \\
\hline Width of head ${ }^{b}$ & 342.6 & 12.2 & 17 & 3.6 & 374.1 & 21.3 & 61 & 5.7 \\
\hline Length of eye $\mathrm{e}^{b}$ & 200.4 & 11 & 17 & 5.5 & 222.1 & 14.2 & 56 & 6.4 \\
\hline Width of eye ${ }^{b}$ & 110.6 & 8.8 & 17 & 7.9 & 126.7 & 8.3 & 55 & 6.6 \\
\hline Length of palpomere $3^{a}$ & 163.5 & 6.6 & 15 & 4 & 171.6 & 7.1 & 60 & 7.1 \\
\hline Length of palpomere $5^{b}$ & 135.3 & 11.5 & 14 & 8.5 & 145.9 & 12.3 & 58 & 8.5 \\
\hline Total length of palpus ${ }^{b}$ & 552 & 21.5 & 14 & 3.9 & 580 & 29.3 & 58 & 5 \\
\hline Maximum width of wing $b$ & 576 & 29.9 & 13 & 5.2 & 620 & 36.4 & 64 & 5.9 \\
\hline Length wing/maximum width of wing ${ }^{a}$ & $a \quad 3.53$ & 0.201 & 13 & 5.7 & 3.35 & 0.225 & 61 & 6.7 \\
\hline Length of $\mathrm{R}_{2}{ }^{a}$ & 547 & 30.4 & 13 & 5.5 & 585 & 58.9 & 65 & 9.7 \\
\hline$\delta^{a}$ & 278 & 34.2 & 12 & 12.3 & 317 & 58.6 & 65 & 18.5 \\
\hline Length of $\mathrm{R}_{3}{ }^{a}$ & 683 & 30.1 & 13 & 4.41 & 723 & 60.2 & 65 & 8.33 \\
\hline Length of anterior femur ${ }^{a}$ & 692 & 33.8 & 11 & 4.9 & 722.5 & 45.5 & 50 & 6.3 \\
\hline Maximum width of spermathecal head ${ }^{a}$ & $\begin{array}{ll}a & 10.49\end{array}$ & 1.8 & 18 & 17.5 & 11.87 & 2.13 & 59 & 17.9 \\
\hline
\end{tabular}

s: standard deviation; $\mathrm{N}$ : number of observations; C.V.: coefficient of variation; $a$ : significant at $5 \% ; b$ : significant at $1 \% ; \delta$ : distance between the distal extremity of $\mathrm{R}_{1}$ and the fork of $\mathrm{R}_{2+3}$.

\section{TABLE VIII}

Dimensions (in $\mu \mathrm{m}$ ) of males for Lutzomyia intermedia from Viana, a low altitude and lower latitude locality of the State of Espírito Santo (ES), and from low altitude and higher latitude localities in the states of Rio de Janeiro and São Paulo

\begin{tabular}{|c|c|c|c|c|c|c|c|c|}
\hline \multirow[b]{2}{*}{ Structures } & \multicolumn{4}{|c|}{ Viana (ES) } & \multicolumn{4}{|c|}{ Rio de Janeiro and São Paulo } \\
\hline & Mean & $\mathrm{s}$ & $\mathrm{N}$ & C. V. & Mean & s & $\mathrm{N}$ & C. V. \\
\hline Length of head ${ }^{b}$ & 318.6 & 12.1 & 17 & 3.8 & 336.3 & 14.8 & 72 & 4.4 \\
\hline Length of palpomere $3^{b}$ & 126.5 & 6.8 & 17 & 5.4 & 133.6 & 7.5 & 74 & 5.6 \\
\hline Length of mesonotum ${ }^{a}$ & 483 & 25 & 16 & 5.2 & 496.5 & 21.8 & 74 & 4.4 \\
\hline Width of wing $b$ & 487.5 & 28.9 & 14 & 5.9 & 525.5 & 31.4 & 74 & 6 \\
\hline Length of $\mathrm{R}_{2}{ }^{a}$ & 448.6 & 33 & 15 & 7.4 & 481.5 & 48.3 & 73 & 10 \\
\hline$\delta^{a}$ & 222.6 & 35.3 & 14 & 15.9 & 250.4 & 43.6 & 74 & 17.4 \\
\hline Length of $\mathrm{R}_{5}{ }^{a}$ & 1130 & 45.6 & 14 & 4 & 1172 & 74.5 & 59 & 6.4 \\
\hline Length of median femur ${ }^{b}$ & 624 & 44.2 & 14 & 7.1 & 655 & 29.2 & 64 & 4.5 \\
\hline Length of style ${ }^{b}$ & 135 & 7.8 & 17 & 5.8 & 140 & 7.9 & 80 & 5.6 \\
\hline Length of lateral lobe ${ }^{a}$ & 271 & 9.8 & 17 & 3.6 & 278 & 12.1 & 80 & 4.4 \\
\hline Length of genital pump ${ }^{b}$ & 198.4 & 10.5 & 17 & 5.3 & 209 & 12.8 & 80 & 6.1 \\
\hline
\end{tabular}

s: standard deviation; $\mathrm{N}$ : number of observations; C.V.: coefficient of variation; $a$ : significant at $5 \%$; $b$ : significant at $1 \% ; \delta$ : distance between the distal extremity of $R_{1}$ and the fork of $R_{2+3}$.

be due to stable conditions at the breeding places of sandflies in the locality. Although the conditions of potential breeding places of sandflies were studied at a Panamanian forest (Rutledge \& Ellenwood $1975 \mathrm{a}, \mathrm{b})$, the relationship between the macroclimatic and microclimatic conditions of these habitats in other environments should be analysed.

Bergmann's rule has been considered as valid for many animals (e. g., Pantelejev 1985, Yon-Tov \& Nix 1986), including insects (Cushman et al. 1993, Stone 1993, Sota 1994). However, its validity was refuted (Geist 1987), because the variation in the ratio between the body surface and the volume of mammals was lower than that foreseen by the rule. Most studies of poikilotherms revised by Atkinson (1994) showed a relationship between the rise in the breeding temperature and a reduction in size.

Lane (1988) revised the studies on the relationship between morphometry and various environmental conditions in Old World sandflies. He emphasized the gradients of variation in measurements and counts between forms of sandflies formerly considered distinct. Lane (1988) observed an influence of the breeding temperature of pupae of 
TABLE IX

Dimensions (in $\mu \mathrm{m}$ ) of females and some of their respective ratios for Lutzomyia intermedia from Venda Nova do Imigrante, in the State of Espírito Santo, collected in June or in December 1994

\begin{tabular}{|c|c|c|c|c|c|c|c|c|}
\hline \multirow[b]{3}{*}{ Structures and ratios } & \multicolumn{8}{|c|}{ Months of collection } \\
\hline & \multicolumn{4}{|c|}{ June } & \multicolumn{4}{|c|}{ December } \\
\hline & Mean & $\mathrm{s}$ & $\mathrm{N}$ & C. V. & Mean & $\mathrm{s}$ & $\mathrm{N}$ & C. V. \\
\hline Width of head ${ }^{a}$ & 357.3 & 13.27 & 11 & 3.71 & 375.9 & 10.65 & 30 & 2.83 \\
\hline Total length of palpus ${ }^{a}$ & 576.7 & 45.32 & 13 & 7.86 & 606 & 23.24 & 33 & 3.83 \\
\hline Length of wing ${ }^{a}$ & 2292 & 89.2 & 13 & 3.89 & 2123 & 91.72 & 34 & 4.32 \\
\hline Length wing/maximum width of wing ${ }^{a}$ & 3.58 & 0.23 & 12 & 6.34 & 3.21 & 0.15 & 33 & 4.69 \\
\hline Length of spermatheca ${ }^{a}$ & 52.36 & 4.43 & 14 & 8.47 & 59.38 & 5.75 & 35 & 9.68 \\
\hline Length of individual spermathecal duct ${ }^{a}$ & 104.3 & 12.13 & 11 & 11.63 & 82.14 & 16.08 & 27 & 19.57 \\
\hline Length common spermathecal duct ${ }^{a}$ & 34.2 & 3.9 & 11 & 11.42 & 43.9 & 8.32 & 24 & 18.95 \\
\hline Length of common spermathecal duct/ & & & & & & & & \\
\hline length of individual spermathecal duct ${ }^{a}$ & 3.1 & 0.57 & 11 & 18.55 & 2.02 & 0.75 & 24 & 37.49 \\
\hline
\end{tabular}

s: standard deviation; N: number of observations; C.V.: coefficient of variation; $a$ : significant at $1 \%$.

Lu. longipalpis on some adult dimensions and recommended caution in the use of quantitative characters to differentiate closely related species. The non-applicability of Bergmann's rule to sandflies of the Lu. intermedia complex in the State of São Paulo, in a trial of them as only one species, corroborated the distinction between $\mathrm{Lu}$. intermedia and Lu. neivai (Pinto, 1926) (Marcondes et al. 1998).

Allen's rule, which states that appendages are proportionally longer in colder areas (Lane 1988), could be applicable to $L u$. intermedia, with regard to legs, palpi and other appendages, and should be studied using a greater number of intact insects. Gogler's Rule suggests that animals from warm and humid areas are more heavily pigmented than those from cool, dry areas (Lane 1988), as noted for Phlebotomus schwetzi and its variety nigrans (Kirk \& Lewis 1951). After establishing a reliable method for the evaluation of pigmentation, the possible validity of this rule for $\mathrm{Lu}$. intermedia should be observed.

$\mathrm{Lu}$. intermedia is strongly suspected as a vector of parasites causing cutaneous leishmaniasis at Viana and other low altitude localities in the State of Espírito Santo, besides being the predominant species at Venda Nova do Imigrante. The occurrence of cutaneous leishmaniasis in this state seems to be limited to $700-750 \mathrm{~m}$ a. s. 1., although $\mathrm{Lu}$. intermedia can be collected even at $930 \mathrm{~m}$ a. s. 1 . (A Falqueto unpublished data). In Ilha Grande, in the State of Rio de Janeiro, where Lu. intermedia and $L u$. migone $i$ were the predominant species and most suspected as vectors, the prevalence of cutaneous leishmaniasis was lower in the higher altitude localities, which were also the least deforested areas (Araujo Filho 1978).
The possible relationship between transmission of parasites of cutaneous leishmaniasis and altitude may be more closely related to factors other than to the size of the insects. The temperature suitable for the evolution of Leishmania in the sandflies (Rioux et al. 1985), the density of the insects and their interaction with reservoirs and human population are some of these factors.

This study invites the conclusion that altitude has a positive influence upon several dimensions and can affect some ratios of Lu. intermedia. Latitude can influence some dimensions, and this should be better studied. Comparative studies on the vectorial efficiency of specimens of this species, bred at different temperatures, would be very useful.

\section{REFERENCES}

Aguiar GM 1993. Estudo sobre a Ecologia dos Flebotomíneos da Serra do Mar, Município de Itaguaí, Estado do Rio de Janeiro, Brasil, Área de Transmissão de Leishmaniose Tegumentar (Diptera, Psychodidae, Phlebotominae), PhD Thesis, Universidade Federal do Paraná, Curitiba, 177 pp.

Araujo Filho NA 1978. Epidemiologia da Leishmaniose Tegumentar Americana na Ilha Grande, Rio de Janeiro. Estudo da Infecção Humana, Reservatórios e Transmissores. Rio de Janeiro, MSc Thesis, Universidade Federal de Rio de Janeiro, Rio de Janeiro, 148 pp.

Atkinson D 1994. Temperature and organism size - a biological law for ectotherms? Adv Ecol Res 25: 158.

Barros GC, Sessa PA, Mattos EA, Carias VRD, Mayrink W, Alencar JTA, Falqueto A, Jesus AC 1985. Foco de leishmaniose tegumentar americana nos municípios de Viana e Cariacica, Estado do Espírito Santo, Brasil. Rev Saúde Públ 19: 146-153.

Cerqueira NL 1943. Novo meio para montagem de 
pequenos insetos em lâminas. Mem Inst Oswaldo Cruz 39: 37-41.

Cushman JH, Lawton JH, Manly BFJ 1993. Latitudinal patterns in European ant assemblages: variation in species richness and body size. Oecologia 95: $30-$ 37.

David JR, Moreteau B, Gauthier JP, Petavy G, Stockel A, Imasheva AG 1994. Reaction norms of size characters in relation to growth temperature in Drosophila melanogaster: An isofemale lines analysis. Gen Sel Evol 26: 229-251.

Ferreira PV 1991. Estatística Experimental Aplicada à Agronomia, Editora Universitária, UFAL, Maceió, $440 \mathrm{pp}$.

Geist V 1987. Bergmann's rule is invalid. Can J Zool 65: 1035-1038.

Haramis LD 1983. Increased adult size correlated with parity in Aedes triseriatus. Mosquito News 43: 7779.

Honek A 1993. Intraspecific variation in body size and fecundity in insects: a general relationship. Oikos 66: 483-492.

James FC 1970. Geographic size in birds and its relationship to climate. Ecology 51: 365-390.

Kelly R, Edman JD 1992. Mosquito size and multiple transmission of avian malaria in the laboratory. $J$ Am Mosquito Control Assoc 8: 386-388.

Kirk R, Lewis DJ 1951. The Phlebotominae of the Ethiopian region. Trans $R$ Ent Soc London 102: 383-510.

Lane RP 1988. Geographic variation in Old World phlebotomine sandflies, p. 77-90. In MW Service, Biosystematics of Haematophagous Insects, Clarendon Press, Oxford.

Marcondes CB 1996. A redescription of Lutzomyia (Nyssomyia) intermedia (Lutz \& Neiva, 1912) and resurrection of L. neivai (Pinto, 1926) (Diptera, Psychodidae, Phlebotominae). Mem Inst Oswaldo Cruz 91: 457-462.

Marcondes CB 1997. Morfometria e DNA Mitocondrial de Populações Sul Americanas de Lutzomyia (Nyssomyia) intermedia (Lutz \& Neiva, 1912) (Diptera, Psychodidae, Phlebotominae), PhD Thesis, Universidade Federal do Paraná, Curitiba, 260 pp.

Marcondes CB, Falqueto A, Lozovei ALL 1997. Influence of preparation methods on the dimensions of Lutzomyia intermedia (Lutz \& Neiva, 1912) (Diptera, Psychodidae, Phlebotominae). Mem Inst Oswaldo Cruz 92: 201-202.

Marcondes CB, Lozovei AL, Galati EAB 1998. The usefulness of Bergmann's rule for the distinction of members of Lutzomyia intermedia species complex
(Diptera, Psychodidae, Phlebotominae). Mem Inst Oswaldo Cruz 93: 363-364.

Pantelejev PA 1985. The character of geographical variation of rodents in Central Europe. Folia Zool 34: $33-41$.

Paraense WL, Chagas AW 1940 Transmissão experimental da leishmaniose visceral americana pelo "Phlebotomus intermedius". Nota prévia. Brasil-Médico 54: 179-180.

Pereira IR, Hoch A 1990. Lutzomyia intermedia as a suspected vector of Leishmania Viannia braziliensis in Bahia State, Brazil. Rev Soc Bras Med Trop 23: 235.

Pinto C 1926. "Phlebotomus neivai" e "Phlebotomus fischeri" n. sp. sp. - sobre o apparelho espiracular dos phlebotomos e seu valor especifico. Sciencia Medica 4: 370-375.

Rangel EF, Barbosa AF, Andrade CA, Souza NA, Wermelinger ED. 1992 Development of Leishmania (Viannia) braziliensis Vianna, 1911 in Lutzomyia intermedia (Lutz \& Neiva, 1912) (Diptera: Psychodidae: Phlebotominae) under experimental conditions. Mem Inst Oswaldo Cruz 87: 235-238.

Rangel EF, Souza NA, Wermelinger ED, Barbosa AF 1984. Infecção natural de Lutzomyia intermedia Lutz \& Neiva, 1912, em área endêmica de leishmaniose tegumentar no Estado do Rio de Janeiro. Mem Inst Oswaldo Cruz 79: 395-396.

Rioux JA, Aboulker JP, Lanotte G, Killick-Kendrick R, Martini-Dumas R 1985. Ecologie des leishmanioses dans le sud de France. 21. Influence de la temperature sur le developement de Leishmania infantum dans Phlebotomus ariasi. Ann Paras Hum Comp 60: 221-230.

Rutledge LC, Ellenwood DA 1975a. Production of Phlebotomine sandflies on the open forest floor in Panama: hydrologic and physiographic relations. Environ Entomol 4: 78-82.

Rutledge LC, Ellenwood DA 1975b. Production of Phlebotomine sandflies on the open forest floor in Panama: phytologic and edaphic relations. Environ Entomol 4: 83-89

Sota T 1994. Larval diapause, size, and autogeny in the mosquito Aedes togoi (Diptera, Culicidae) from tropical to subarctic zones. Can J Zool 72: 14621468.

Stone GN 1993. Endothermy in the solitary bee Anthophora plumipes: Independent measures of thermoregulatory ability, costs of warm-up and the role of body size. J Exp Biol 174: 299-320.

Yon-Tov Y, Nix H 1986. Climatological correlates for body size in five species of Australian mammals. Biol J Linn Soc 29: 245-262. 